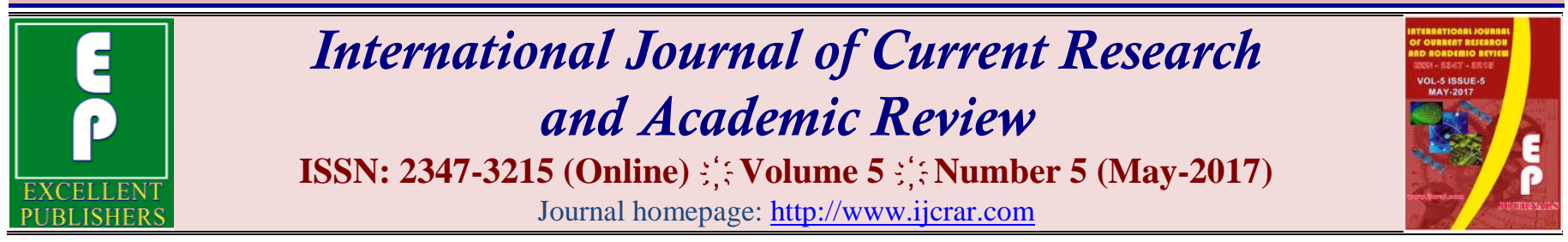

doi: $\underline{\text { https://doi.org/10.20546/ijcrar.2017.505.010 }}$

\title{
Birth Preparedness and Complication Readiness among Women Availing Obstetric Services at a Rural Maternity Hospital in South Karnataka, India
}

\author{
J. Rakesh*, Avita Rose Johnson, Angeline, Soumya and Twinkle Agrawal
}

Department of Community Health, St John's Medical College, Bangalore, India

*Corresponding author:

\begin{abstract}
Birth Preparedness and Complication Readiness (BP/CR) is a strategy to promote the timely use of skilled maternal and neonatal care, especially during childbirth, based on the theory that preparing for childbirth and being ready for complications reduces delays in obtaining this care and prevents many maternal and neonatal deaths. The objective of study is to assess birth preparedness and complication readiness (BP/CR) and its associated factors among women availing obstetric services at a rural maternity hospital in south Karnataka. A cross sectional study was carried out at a rural maternity hospital from Jan-Feb 2016. Convenience sampling was used to study 200 women attending the hospital for delivery. An interview schedule consisting of sociodemographic details and assessment of BP/CR (JHPIEGO tool for monitoring BP/CR (2004)) was used. Among the 200 women interviewed, $76 \%$ were aware of any one danger sign in women during pregnancy, $23.5 \%$ during labour, $23.5 \%$ after giving birth and $61 \%$ in a newborn. The proportion of woman who was aware of any three danger signs was found to be extremely low. All had, in advance arranged money for delivery, $34 \%$ had arranged for transport, $72 \%$ had identified the health facility for delivery and none had identified a blood donor. There was poor knowledge about key danger signs in women during pregnancy, labour, post partum and in the new born which would lead to first delay. Knowledge about BP/CR is insufficient especially in case of identifying transport and blood donor which may lead to second delay. BP/CR should be discussed repeatedly during antenatal visits.
\end{abstract}

\author{
Article Info \\ Accepted: 05 May 2017 \\ Available Online: 20 May 2017
}

\section{Keywords}

Birth preparedness, complication readiness, antenatal women, rural.

\section{Introduction}

Maternal mortality is the priority issue in health policy and research in developing countries due to high rates of maternal deaths. Globally an estimated 2,87,000 maternal deaths occurred in 2010 of which $19 \%(56,000)$ was recorded in India. Most of maternal deaths occur in the developing world. (Statistical Inst, Delhi, 2012). As per Office of Registrar General of India estimate in 2011-13, the Maternal Mortality Ratio (MMR) in India was 167 per one lakh live births and in Karnataka was 133 per one lakh live births respectively. These figures are higher with respect to country`s Millennium Development Goal to reduce MMR by 109 per one lakh live births by 2015 (MDG, 2015).

Thaddeus and Maine have documented "three delays" in seeking, reaching, and obtaining appropriate care as the crucial factors for maternal mortality, Thaddeus et al., (1994). The Maternal and Neonatal Health (MNH) 
Program of Johns Hopkins Program for International Education in Gynecology and Obstetrics (JHPIEGO) developed the birth-preparedness and complication readiness matrix to address these three delays at various levels, including the pregnant woman, her family, her community, health providers, health facilities, and policy-makers during pregnancy, childbirth, and the postpartum period (JHPIEGO, 2001).

Birth Preparedness and Complication Readiness (BPCR) is the process of planning for normal birth and anticipating the actions needed in case of an emergency. It includes identifying a trained birth attendant for delivery, identifying a health facility for emergency, arranging for transport for delivery and/or obstetric emergency, and saving money for delivery and identification of compatible blood donors in case of emergency. Complication readiness raises awareness of danger signs among women, families, and the community, thereby improving problem recognition, reduces the delay in deciding to seek care and hastens reaching medical facilities (JHPIEGO, 2001).

This study aims to assess the birth preparedness and complication readiness (BP/CR) and its associated factors among women availing obstetric services at a rural maternity hospital in south Karnataka. The findings of this study will provide important information regarding prevalence, practice and determinants of BP/CR. This will help policy makers and public health specialists to design community based interventions which will encourage pregnant women and their families to be prepared for birth and its complications.

\section{Materials and Methods}

This was a cross sectional study done during the period of January-February 2016. Institutional Ethics approval was obtained for the study. The sample size calculated was 200 by using BPCR index (41\%) from a similar study conducted in Delhi, Acharya et al., (2015). 200 women attending a rural maternity at Ramanagara taluk in southern Karnataka for delivery were interviewed. A written informed consent was taken prior to interview. The interview schedule was divided into three sections: Section I -socio demographic detail of the subjects, Section II -obstetric details of the subjects, Section IIIKnowledge of birth preparedness and its practices. The questionnaire was adapted from the 'Monitoring birth preparedness and complication readiness- tools and indicators for maternal and newborn health matrix' from the Maternal and Neonatal Health (MNH) Program of the JHPIEGO (2004).

The data was entered in Microsoft Excel and analyzed using SPSS version 16. Measures of central tendency like mean and standard deviation were used to describe the socio-demographic variables. Test of association like chi-square test and Fischer's exact test were performed to look for association between various sociodemographic and obstetric factors, and BPCR.

\section{Results and Discussion}

The questionnaire was administered to 200 women attending the hospital for delivery and the response rate was $100 \%$.

Of the 200 women interviewed, mean age was $22.74+$ 2.607 years. The youngest was 18 years and the oldest 31 years. Majority were home makers (96\%) and most of them belong to either join/extended/three generation family $(80.5 \%)$. Majority of them were Hindu by religion (86\%). The mean duration of schooling was $11.9+2.73$ years and the mean number of family members was found to be $5.3 \pm 1.653$. The average per capita income was Rs $1896+1893.9$ (IQR: 1000-2249) and majority of them belong to lower socio economic status according Modified B G Prasad classification. 5.5\% of them were married before 18 years of age. Mean age at marriage was $20.31 \pm 1.95$ years and (range $=15-25$ years). The mean gestational age of the study population was $39.05 \pm 0.9$ weeks. The average number of antenatal visits done was $12.1+1.88$. Most of the women were primigravida $133(66.5 \%)$. About $18(9 \%)$ of the study subjects had previous history of abortion and 5(2.5\%) had reported previous deaths of the children.

About $24 \%$ of the respondents were not aware of any danger signs and $76 \%$ reported any one danger sign during pregnancy. $76.5 \%$ of them don't know any danger signs during labour and delivery and $23.5 \%$ reported any one danger sign during labour and delivery. Majority of them $(76.5 \%)$ don't know any danger signs in postpartum period and $23.5 \%$ knew any one danger signs in post-partum period. $39 \%$ of the respondent doesn't know any danger signs in new born child and $61 \%$ knew any one danger signs in a new born child. In advance, all the study subjects had arranged money for delivery, $34 \%$ had arranged for transport, $72 \%$ had identified the health facility for delivery and none had identified a blood donor. (See Table 3) 
Women above the age group of 21 years had identified the mode of transport in advance as compared to younger women $(<20$ years $)$ and which was statistically significant (See Table 4). Women receiving formal education more than 10 years had identified more, the place delivery and mode of transport as compared to other group (<10years) and it was not statistically significant. Also there was no statistically significant difference in the knowledge on danger signs either during pregnancy, labour, post partum period, in the new born and educational levels of respondent.

Women from upper class and upper middle class have better knowledge of danger signs in the new born and it was statistically significant. Also statistically significant difference was seen among the lower SES classes against the knowledge of danger signs in the women during pregnancy.

Multi gravid women had statistically significant better knowledge of danger signs during pregnancy as compared to primigravida women.

Information provided by the health care providers was found to be low. About 34.5\% were informed of the danger signs during pregnancy, labour, post partum period and in the new born. Health care providers had informed in advance: to arrange transport at the time of delivery $(37.5 \%)$, to save money for the delivery $(36 \%)$ and to identify the place of delivery $(34.5 \%)$. None of them had advised to arrange a blood donor in advance. (Table 5).

In this study, of 200 antenatal woman $76 \%$ were aware of any one danger sign in women during pregnancy, $23.5 \%$ during labour, $23.5 \%$ after giving birth and $61 \%$ in a newborn. The proportion of woman who was aware of any three danger signs was found to be extremely low. The findings in this study was higher compared to the study results conducted by Acharya et al., (2015), among the antenatal women in Delhi in 2012 as $27.8 \%$ were aware of any one danger sign during pregnancy, $6.7 \%$ during labour and $0.7 \%$ after giving birth,. Another study conducted among the antenatal women in $2^{\text {nd }} / 3^{\text {rd }}$ trimester and recently delivered women in west Bengal in 2011 reported that, among the 117 antenatal women $14.5 \%$ were aware of any one danger sign in women during pregnancy, $17.1 \%$ during labour, $12.8 \%$ after giving birth and $29.1 \%$ in a newborn. And the awareness among the recently delivered women $(<1$ year) reported that $23.5 \%$ were aware of any one danger sign in women during pregnancy, $18.1 \%$ during labour, $8.8 \%$ after giving birth and $41.2 \%$ in a newborn, Mukhopadhyay et al., (2015). A study done in Nigeria in 2004 among the antenatal women reported that $49.6 \%$ were aware of the danger signs during pregnancy, labour and after giving birth (Tobin et al., 2014).

Table.1 Number of key danger signs mentioned by antenatal women during pregnancy, labour and child birth, after child birth and in newborn. $(n=200)$

\begin{tabular}{|l|l|l|l|l|}
\hline $\begin{array}{l}\text { No. of danger } \\
\text { signs }\end{array}$ & $\begin{array}{l}\text { Key danger } \\
\text { signs during } \\
\text { pregnancy }(\%)\end{array}$ & $\begin{array}{l}\text { Key danger } \\
\text { signs during } \\
\text { labour }(\%)\end{array}$ & $\begin{array}{l}\text { Key danger } \\
\text { signs after } \\
\text { child birth (\%) }\end{array}$ & $\begin{array}{l}\text { Key danger } \\
\text { signs in } \\
\text { newborn (\%) }\end{array}$ \\
\hline $\begin{array}{l}\text { Did not know any } \\
\text { key danger sign }\end{array}$ & $47(23.5)$ & $153(76.5)$ & $149(74.5)$ & $74(37)$ \\
\hline Any 1 danger sign & $131(65.5)$ & $41(20.5)$ & $42(21)$ & $88(44)$ \\
\hline Any 2 danger sign & $17(8.5)$ & $5(2.5)$ & $9(4.5)$ & $32(16)$ \\
\hline Any 3 danger sign & $5(2.5)$ & $1(0.5)$ & $0(0)$ & $6(3)$ \\
\hline
\end{tabular}


Table.2 Distribution of study population according to awareness of key danger signs in Pregnancy, Labour/Childbirth, Post partum and Newborn Period $(n=200)$

\begin{tabular}{|l|l|}
\hline Awareness of key danger signs & Frequency n (\%) \\
\hline 1. Key danger signs during pregnancy \\
\hline Severe vaginal bleeding & $149(74.5)$ \\
\hline "Water break" without labour & $19(9.5)$ \\
\hline Convulsions & $6(3)$ \\
\hline Absence of foetal movements & $4(2)$ \\
\hline Swollen hands or face & $3(1.3)$ \\
\hline Blurred vision & $3(1.3)$ \\
\hline Reduced foetal movements & $3(1.3)$ \\
\hline 2. Key danger signs during childbirth \& labour \\
\hline Labour duration > 12 hours & $26(13)$ \\
\hline Severe vaginal bleeding & $19(9.5)$ \\
\hline Convulsions & $9(4.5)$ \\
\hline Retained placenta & $7(3.5)$ \\
\hline 3. Key danger signs in women after child birth \\
\hline High fever & $23(13)$ \\
\hline Vaginal bleeding & $19(9.5)$ \\
\hline Foul smelling discharge & $9(4.5)$ \\
\hline Pain/swelling in Breast & $9(4.5)$ \\
\hline 4. Key danger signs in newborn \\
\hline Fever/hypothermia & $71(35.5)$ \\
\hline Yellowing of skin & $42(21)$ \\
\hline convulsions & $22(11)$ \\
\hline Fast breathing & $19(9.5)$ \\
\hline Poor feeding & $16(8)$ \\
\hline
\end{tabular}

Table.3 Status of Birth Preparedness and Complication Readiness indicators among the Study Population ( $\mathrm{n}=200)$

\begin{tabular}{|l|l|}
\hline Indicators & Frequency (\%) \\
\hline Identified place of delivery & $144(72)$ \\
\hline Identified mode of transport & $68(34)$ \\
\hline Saved money & $200(100)$ \\
\hline Identified a blood donor & $0(0)$ \\
\hline
\end{tabular}


Table.4 Association of socio-demographic and obstetric factors with BP/CR

\begin{tabular}{|c|c|c|c|c|c|c|c|c|}
\hline Variable & Category & $\begin{array}{l}\text { Study } \\
\text { subjects }\end{array}$ & $\begin{array}{l}\text { At least } \\
\text { one } \\
\text { key } \\
\text { danger } \\
\text { sign of } \\
\text { pregnancy }\end{array}$ & $\begin{array}{l}\text { At least } \\
\text { one } \\
\text { key } \\
\text { danger } \\
\text { sign of } \\
\text { labor }\end{array}$ & $\begin{array}{l}\text { At least } \\
\text { one } \\
\text { key } \\
\text { danger } \\
\text { sign of } \\
\text { postpartu } \\
\text { m }\end{array}$ & $\begin{array}{l}\text { At least } \\
\text { one } \\
\text { key } \\
\text { danger } \\
\text { sign of } \\
\text { newborn }\end{array}$ & $\begin{array}{l}\text { Identified } \\
\text { place of } \\
\text { delivery }\end{array}$ & $\begin{array}{l}\text { Identified } \\
\text { mode of } \\
\text { transport }\end{array}$ \\
\hline $\begin{array}{l}\text { Age } \\
\text { group }\end{array}$ & $\begin{array}{l}18-20 \\
21-25 y r s \\
>25 y r s\end{array}$ & $\begin{array}{l}42 \\
127 \\
31\end{array}$ & $\begin{array}{l}28(66.7) \\
100(78.7) \\
24(77.4)\end{array}$ & $\begin{array}{l}10(23.8) \\
30(23.6) \\
7(22.6)\end{array}$ & $\begin{array}{l}12(28.6) \\
32(25.2) \\
3(9.7)\end{array}$ & \begin{tabular}{|l|}
$25(59.5)$ \\
$79(62.2)$ \\
$18(58.1)$
\end{tabular} & \begin{tabular}{|l|}
$30(71.4)$ \\
$91(71.7)$ \\
$23(74.2)$
\end{tabular} & $\begin{array}{l}6(14.3)^{*} \\
51(40.2) \\
11(35.5)\end{array}$ \\
\hline Religion & $\begin{array}{l}\text { Hindu } \\
\text { Muslim } \\
\text { Christian }\end{array}$ & $\begin{array}{l}172 \\
18 \\
10\end{array}$ & $\begin{array}{l}129(75) \\
15(83.3) \\
8(80)\end{array}$ & $\begin{array}{l}39(22.7) \\
6(33.3) \\
2(20)\end{array}$ & $\begin{array}{l}40(23.3) \\
2(11.1) \\
5(50)\end{array}$ & $\begin{array}{l}103(59.9 \\
) \\
11(61.1) \\
8(80)\end{array}$ & \begin{tabular}{|l}
$124(72.1)$ \\
$12(66.7)$ \\
$8(80)$
\end{tabular} & $\begin{array}{l}\text { 61(35.5) } \\
2(11.1) \\
5(50)\end{array}$ \\
\hline $\begin{array}{l}\text { Educatio } \\
\mathrm{n}\end{array}$ & $\begin{array}{l}0-5 \\
6-10 \\
>10\end{array}$ & $\begin{array}{l}9 \\
70 \\
121\end{array}$ & $\begin{array}{l}9(100) \\
54(22.9) \\
89(73.6)\end{array}$ & $\begin{array}{l}2(22.2) \\
19(27.1) \\
26(21.5)\end{array}$ & $\begin{array}{l}2(22.2) \\
19(27.1) \\
26(21.5\end{array}$ & $\begin{array}{l}6(66.7) \\
45(64.3) \\
71(58.7)\end{array}$ & \begin{tabular}{|l|}
$5(55.6)$ \\
$55(75.7)$ \\
$86(71.1)$
\end{tabular} & $\begin{array}{l}3(33.3) \\
29(41.4) \\
71(58.7)\end{array}$ \\
\hline $\begin{array}{l}\text { Occupati } \\
\text { on }\end{array}$ & $\begin{array}{l}\text { Home makers } \\
\text { others }\end{array}$ & $\begin{array}{l}192 \\
8\end{array}$ & $\begin{array}{l}147(76.6) \\
5(62.5)\end{array}$ & $\begin{array}{l}46(24) \\
1(12.5)\end{array}$ & $\begin{array}{l}46(24) \\
1(12.5)\end{array}$ & $\begin{array}{l}118(74) \\
4(50)\end{array}$ & \begin{tabular}{|l}
$139(72.4)$ \\
$5(62.5)$
\end{tabular} & $\begin{array}{l}62(32.3) \\
6(75)\end{array}$ \\
\hline $\begin{array}{l}\text { Type of } \\
\text { family }\end{array}$ & $\begin{array}{l}\text { Nuclear } \\
\text { Three/extended } \\
\text { /joint }\end{array}$ & $\begin{array}{l}39 \\
161\end{array}$ & $\begin{array}{l}23(59) * \\
129(80.1)\end{array}$ & $\begin{array}{l}7(17.9) \\
40(24.8)\end{array}$ & $\begin{array}{l}9(23.1) \\
38(23.6)\end{array}$ & \begin{tabular}{|l|}
$28(71.8)$ \\
$94(58.4)$
\end{tabular} & \begin{tabular}{|l|}
$25(64.1)$ \\
$119(73.9)$
\end{tabular} & $\begin{array}{l}13(33.3) \\
15(34.2)\end{array}$ \\
\hline $\begin{array}{l}\text { Socio } \\
\text { economi } \\
\text { c status } \\
\text { (Modifie } \\
\text { d BG } \\
\text { Prasad) }\end{array}$ & $\begin{array}{l}\text { Class I } \\
\text { Class } \quad \text { II } \\
\text { Class III } \\
\text { Class IV } \\
\text { Class V }\end{array}$ & $\begin{array}{l}2 \\
11 \\
57 \\
104 \\
26\end{array}$ & $\begin{array}{l}1(50) * \\
4(36.4) \\
46(80.7) \\
79(76) \\
22(84.6)\end{array}$ & $\begin{array}{l}1(50) \\
5(45.5) \\
13(22.8) \\
21(20.2) \\
7(26.9)\end{array}$ & $\begin{array}{l}1(50) \\
3(27.3) \\
14(24.6) \\
24(23.1) \\
5(19.2)\end{array}$ & $\begin{array}{l}2(100) * \\
9(81.8) \\
42(73.7) \\
54(51.9) \\
15(57.7)\end{array}$ & $\begin{array}{l}1(50) * \\
8(72.7) \\
33(57.9) \\
78(75) \\
24(92.3)\end{array}$ & $\begin{array}{l}0(0) \\
2(18.2) \\
25(43.9) \\
32(30.8) \\
9(34.6)\end{array}$ \\
\hline $\begin{array}{l}\text { Gravida } \\
\text { status }\end{array}$ & $\begin{array}{l}\text { Primi } \\
\text { Multi }\end{array}$ & $\begin{array}{l}133 \\
67\end{array}$ & $\begin{array}{l}99(74.4) \\
53(79.1)\end{array}$ & $\begin{array}{l}34(25.6) \\
13(19.4)\end{array}$ & $\begin{array}{l}31(23.3) \\
16(23.9)\end{array}$ & \begin{tabular}{|l|}
$82(61.7)$ \\
$40(59.7)$
\end{tabular} & \begin{tabular}{|l|}
$95(71.4)$ \\
$49(73.1)$
\end{tabular} & $\begin{array}{l}44(33.1) \\
24(35.8)\end{array}$ \\
\hline Abortion & $\begin{array}{l}\text { Yes } \\
\text { No }\end{array}$ & $\begin{array}{l}18 \\
182\end{array}$ & $\begin{array}{l}12(66.7) \\
140(76.9)\end{array}$ & $\begin{array}{l}4(22.2) \\
43(23.6)\end{array}$ & $\begin{array}{l}1(5.6) \\
46(25.3)\end{array}$ & $\begin{array}{l}9(50) \\
113(62.1 \\
)\end{array}$ & \begin{tabular}{|l|}
$14(77.8)$ \\
$130(71.4)$
\end{tabular} & $\begin{array}{l}3(16.7) \\
65(35.7)\end{array}$ \\
\hline
\end{tabular}

$* \mathrm{p}$ value $<0.05$ (statistically significant) 
Table.5 Information provided from health care providers $(n=200)$

\begin{tabular}{|l|l|}
\hline Information regarding & Frequency (\%) \\
\hline $\begin{array}{l}\text { Danger signs during pregnancy, labour, post } \\
\text { partum period and in newborn }\end{array}$ & $69(34.5 \%)$ \\
\hline $\begin{array}{l}\text { Identification of the place of delivery in } \\
\text { advance. }\end{array}$ & $69(34.5 \%)$ \\
\hline $\begin{array}{l}\text { Informing arrangement of transport in } \\
\text { advance. }\end{array}$ & $75(37.5 \%)$ \\
\hline $\begin{array}{l}\text { Educating to save money for the delivery in } \\
\text { advance }\end{array}$ & $72(36 \%)$ \\
\hline Arrangement of the blood donor in advance. & $0(0 \%)$ \\
\hline
\end{tabular}

Home makers were more aware of the key danger signs than working class women. This could be probably due to the ASHA/ANMs had better opportunity to educate the home makers as compared to working class women. Women belonging to the three generation/extended/joint family were more aware of key danger signs during pregnancy as compared to those staying in nuclear family and the difference found to be statistically significant. Women of high socio economic status were more aware of the key danger signs in the new born and it was statistically significant. Women belonging to the low socio economic status were more aware of key danger signs during pregnancy which was statistically significant.

A study done by Acharya et al., (2015), showed that parity, younger age, education, joint family system, and husband's education and occupation were associated with having high BP/CR. Woman's education and her spouse's education up to middle school and above were strong predictors of BPACR.

In the present study, all had in advance arranged money for delivery, 34\% had arranged for transport, $72 \%$ had identified the health facility for delivery and none had identified a blood donor. A study done by Acharya et al., (2015) among the antenatal women reported that $81.1 \%$ had identified skilled provider for delivery, $48.9 \%$ had saved money and $44.1 \%$ had arranged transport in advance. A study done by Tobin et al., (2014) in Nigeria reported that $87.4 \%$ had identified the place of delivery in advance and $11.3 \%$ had saved money.

In this study women above the age group of 21 years had identified the mode of transport in advance as compared to younger women $(<20$ years $)$ and which was statistically significant. Most of the study subjects belonged to the age group of 21-25 years out of which
$40.2 \%$ had identified the mode of transport in advance. Women with higher educational status $(<10$ years $)$ had identified mode of transport in advance than lower educational status women though the difference was not statistically significant. Lower socio-economic status women had identified the place of delivery more compared to higher socio economic status women and the difference was statistically significant.

None of the women interviewed had identified the blood donor and all of them had saved money for the delivery in advance. A study done by Acharya et al., (2015) reported that education of women and their husbands, occupation of husband and type of family were statistically significantly associated with the women who had made arrangements for transport before delivery.

In conclusion, there was poor knowledge about key danger signs in women during pregnancy, labour, post partum and in the new born which would lead to first delay. Socio demographic factors like age, type of family and socio economic status found to be significantly associated with BP/CR. Knowledge about BP/CR is insufficient especially in case of identifying transport, saving the money for delivery and blood donor which may lead to second delay. And information provided by the health care providers was found to be low. Thus knowledge regarding BP/CR needs to be imparted to all pregnant mothers from first antenatal visit and should be reinforced subsequently at each ante natal visits or the during the home visits done by the health care providers.

\section{Recommendations}

Information regarding BPCR should be advocated to pregnant women during routine antenatal visits as well as from village level workers like ASHA and Anganwadi worker during their home visits. Health education 
sessions to be conducted among the antenatal women in the community including the women of reproductive age group regarding BPCR and its components. Training programmes to be held for the health personnel working specifically at the grass root level like ASHA, Anganwadi worker about the components of BPCR and advised them to reinforce the components of BP/CR to pregnant women at each visits made by them.

\section{References}

Acharya A et al (2015), Making Pregnancy Safer-Birth Preparedness and Complication Readiness Study Among Antenatal Women Attendees of A Primary Health Center, Delhi. Indian J Community Med [Internet]. 2015;40(2):127.

JHPIEGO(2001) Maternal and Neonatal Health Program. Birth preparedness and complication readiness: a matrix of shared responsibilities. Baltimore, MD: JHPIEGO; 2001. p.12

JHPIEGO(2004). Monitoring birth preparedness and complication readiness . Tools and indicators for

\section{How to cite this article:}

Rakesh, J., Avita Rose Johnson, Angeline, Soumya and Twinkle Agrawal. 2017. Birth Preparedness and Complication Readiness among Women Availing Obstetric Services at a Rural Maternity Hospital in South Karnataka, India. Int.J.Curr.Res.Aca.Rev. 5(5), 78-84. doi: https://doi.org/10.20546/ijcrar.2017.505.010 maternal and newborn health. Baltimore, JHPIEGO, 2004.

MDG(2015), Millennium development goal India country 2015. http://mospi.nic.in/Mospi_New/upload/mdg_26feb1 5.pdf

Mukhopadhyay, D.K. et al., (2015). Status of birth preparedness and complication readiness in Uttar Dinajpur District, West Bengal. Indian J Public Health., 57(3):147-54. http://www.ncbi.nlm.nih.gov/pubmed/24125929

Stastical institute Delhi (2012) available from http://www.isidelhi.org.in/hrnews/HR_THEMATIC _ISSUES/Health/Health2012.pdf

Thaddeus S et al(1994), Too far to walk: Maternal mortality in context. Soc Sci Med 1994;38:1091110

Tobin, E. et al., (2014). Assessment of birth preparedness and complication readiness among pregnant women attending Primary Health Care Centres in Edo State, Nigeria. Ann Niger Med. 8(2): 76. 